\title{
Erratum to: International entrepreneurship in and from emerging economies
}

\section{Christian Felzensztein ${ }^{1}$}

Published online: 30 April 2016

(C) Springer Science+Business Media New York 2016

\section{Erratum to: J Int Entrep}

DOI 10.1007/s10843-016-0175-y

The original version of this article was revised: the article title was corrected as shown above. In the previous version, the word "economies" was omitted.

The online version of the original article can be found at http://dx.doi.org/10.1007/s10843-016-0175-y.

\section{Christian Felzensztein}

c.felzensztein@kingston.ac.uk

1 Global Entrepreneurship Development Centre, Kingston University, London, UK

Springer 